\title{
Representation of Pluralism in Literary History from Riau Island, Indonesia
}

\author{
By $M u^{\prime} j i z a h^{*}$
}

\begin{abstract}
One kind of the genre in literature is literary history, often called historiography traditional. In $17^{\text {th }}-19^{\text {th }}$ century this type of work was commonly found in the Riau Island manuscripts, especially in Pulau Penyengat. This area in ancient times became a scriptorium of Malay manuscripts. Several authors and scribes' works, such as Raja Haji, Raja Ali Haji, Raja Ibrahim, and Salamah Binti Ambar and a descendant of Encik Ismail bin Datuk Karkun, were found in the region. Their works among others are Tuhafat An-Nafis, Silsilah Melayu, dan Bugis, and Hikayat Negeri Johor. In Indonesia, the manuscripts are kept in the National Library of Indonesia in Jakarta and Indrasakti Foundation in Riau Island. Some manuscripts among others were found in the Leiden University Library and KITLV Library in Netherlands. The historiography is useful to explore the source of historical knowledge, especially in search for understanding the process in the formation of Malay ethnic group with plural identities in Indonesia. The aim is to find representation of pluralism in the past Malay literary history which has contributed and strengthened nationalism. In the study we use qualititative research and descriptive methods of analysis. The research has found that the Malay ethnic group in Indonesia derived from various ethnic groups that integrated and became a nation with pluralities. According to the myth, the Malay ethnic group came from the unity between the upper-world or the angelic world and the under-world depicted as the marriage between Putri Junjung Buih and a human being. This marriage is a symbol of unity of microcosm and macrocosm. From this unity many kings were born and then, they integrated in the other nations ranging from Macedonia, China, India, to many tribes in other countries. The pluralism was established through marriage, trade, and expansion of power.
\end{abstract}

Keywords: Identity, Integration, Pluralism, Traditional historiography, Unity

\section{Introduction}

It is known by many that Indonesian people are multi-ethnic, multi-lingual, multi-cultural and multi-religious. C. van Vollenhoven (1918-1933) classified Indonesian tribes or ethnic groups based on their cultural differences into 19 customary law areas (adatrechtskringen). Melalatoa (1995) developed this classification to include 500 ethnic groups in Indonesia which ranks second after India for its biggest numbers of multi-ethnic groups. With multi ethnic groups and cultures, Indonesia has some benefits; among others are strategic advantages, political advantages, and cultural advantages in the form of social and national strengths known as the archipelagic state of the Republic of Indonesia.

Those ethnic groups are scattered in various places in Indonesia. In Sumatra there are Acehnese and the Gayo, the Minangkabau, the Malayan Riau, Malayan Palembang, and Kerinci. In Jawa, there are Javanese, Sundanese, as well as Malay ethnic group (Betawi). In Bali and West Nusa Tenggara, there are three ethnic groups, namely, the Balinese, the Sasak people, and Bimanese. In Borneo, there

\footnotetext{
* Associate Researcher, National Agency for Language Development and Cultivation, Ministry of Education and Culture, Indonesia.
} 
are Malay people in Pontianak, Sambas, Banjarmasin, and Kutai besides the Dayaks and Banjar tribe. In Celebes there are other tribes or ethnic groups, such as the Bugis, Makassar, Mandar, Torajan, and Wolio tribes. In Moluccas, there are Ternate, Tidore, Bacan, and Ambonese. Many kinds of tribes can also be found in Papua.

Each ethnic group has its own culture, faith, and language. In the past there were a lot of faiths among those ethnic groups, such as Kaharingan and Kejawen. Later on, only Islam, Christianity, Catholicism, Buddhism, Hinduism, and Confucianism were acknowledged in Indonesia. Currently, after a new policy on decentralization was issued, a number of ethnic groups have revitalized their old traditions of faith.

Those ethnic groups have their own local languages for communication. According to Badan and Bahasa (2016), there are about 652 local languages in Indonesia, some of which have no longer been used or lost their popularity among local people. Within those local languages the ethnic groups keep their local wisdom and philosophies.

These diversities will surely become rich and positive qualities if they have been managed properly by the Indonesian government. Accordingly, Indonesia will become a united nation with its pluralities. Indeed, pluralism has been accepted, yet, it would turn to a boomerang if the government mismanaged it through its strategic policy. It may trigger separation. It is for integration that Indonesian forefathers adopted the principle of Unity in Diversity (Bhineka Tunggal Ika). This philosophy has been obeyed by the whole society.

Besides the philosophy of pluralism, Indonesia also bases its state ideology on Pancasila (the Five Principles). Pancasila basically contains five principles on how Indonesian people live in the country. Both the ideology and philosophy have become national guide and insight for people in Indonesia. They are represented in its politics, socio-cultural relationship, and arts. There is also the 1945 Constitution of the Republic of Indonesia. In article 29 section 2, there is a statement that the state government guarantees everyone to perform his or her own belief and religion. Accordingly, each religion's follower should be tolerant to other religion's followers. This article is the realization of the first principle of Pancasila. Belief in God the Almighty.

Recently Indonesia has experienced a conflict upon pluralism. The Unitary State of the Republic of Indonesia has been undermined by several critical issues upon racism known as SARA (stands for Suku, Ras, and Agama). One of the latest incidents was about the campaign in the previous election in Jakarta resulted in the arrest of Basuki Tjahaya Purnama, the former Governor of the Greater Area of Jakarta, with accusation of blasphemy.

There is vivid evidence that state control based on plural societies is not an easy task to do. Every part of the society, including the government as well as individuals, should be wise enough in taking decision and should engage in selfreflection to work together in harmony.

Before the independence of Indonesia, the control of pluralism in the society had been held by the rulers of many kingdoms in Nusantara (ancient name of Indonesia). Since August 17, 1945, all the kingdoms have agreed to unite into one 
nation, the Indonesian people. The people also chose Malay language as the sole national language used in the country. This language has been later known as Bahasa Indonesia, and has become the state official language of Indonesia.

The history of this nation is an interesting object of research, especially the process of adopting the Malay language as the national language of Indonesia. Before 1945, the Malay sovereignties were spread out all over the country. This ethnic group is identical in the use of the Malay language in five big islands, in Aceh, Padang, Riau, Jambi, and Palembang (in Sumatra island), in Java, the Malay ethnic group resides in Batavia/Jakarta. The Malay ethnic group also lives throughout the Borneo island. In Celebes island, the Malay ethnic group lives in Makassar and Buton, and this ethnic group also lives in Moluccas, Ternate, Tidore and in Papua.

Among the whole Malay ethnic groups, the Malay people who lived in Riau were the most advanced due to its geographical location which is close to the Malacca straits. During the time period from the $16^{\text {th }}$ century to the $19^{\text {th }}$ century, Malacca became the trade center where people came to negotiate. In terms of language, the Malay people in Riau has also shown their advancement. In the $19^{\text {th }}$ century, intellectuals in Riau were aware of the importance of a standard Malay language for a medium of communication. Therefore, Raja Ali Haji wrote Malay grammar, Bustanul Katibin and a dictionary of the Malay language, Kitab Pengetahuan Bahasa. Based on those two references, Kridalaksana (1998) stated that Malay language in Riau is the standard language used among the Malay people. Numerous works and handwritten manuscripts were also published due to those two references. Those works function as social documents that record of the Malay people's thought in Riau Island.

Pulau Penyegat is one of so many places in Riau with abundant collections of manuscripts. This island has once become the center of the government in Riau. Pulau Penyegat has become one of the places in Riau for copying manuscripts or scriptoriums (Mu'jizah 2013). Numerous genres of literary work in the form of hikayat and syair have been found in this island. Among those works, the most popular ones are traditional historiographies. Those works were composed by Raja Haji, Raja Ali Haji, Raja Ibrahim, and Salamah Binti Ambar, and the descendants of the famous author, Encik Ismail bin Datuk Karkun.

Samples of the traditional historiography found in this area are Tuhfat An_Nafis, Sejarah Raja-Raja Riau, Sejarah Melayu, Silsilah Melayu dan Bugis, Syair Sultan Mahmudin Lingga, and Hikayat Negeri Johor. Instead of Myth, historical elements represent the strength of historiography. The Bugis and Makassar with their strong tradition in historical records also gave strong influence in those works. The manuscripts are securely kept in several places, such as in Indrasakti Foundation in Riau Island, in the National Library of Indonesia in Jakarta, and also in Leiden University Library and KITLV Library in the Netherlands.

Those manuscripts represent a record of the social documents and livelihood of the society in the past. The idea of pluralism among Malay people can also be found in those manuscripts. They believed that plural society derived from their ancestors. Those people had survived through various phases in the history during 
multi-cultural encounters. Eventually, the multicultural encounters had created a certain society with pluralities. Numerous nations and ethnic groups had merged and assimilated into a complex society as depicted in the historiography.

One of the examples is the belief that Malay people were the descendant of Sultan Iskandar Zulkarnain from Macedonia. In another literary work, they were the offspring of Sea Goddess and Putri Junjung Buih. Those different versions of family tree did not have any effect on the society under the sovereignty of the Malay Kingdom. Multi-cultural encounters also happened among other Malay ethnic groups - among the Bugis, the Makassar, among the Minangkabau, the Acehnese, and the Jambi people. The existence of those ethnic groups and their reciprocal influence have become the topic of this paper which focuses on the pluralism in Malay society in literary history in Riau.

The objective of this paper is to explore the process in the formation of plural ethnic groups in Malay and to find its representation in the historiography. Hopefully, these findings will contribute to better understanding of the processes in the formation of pluralistic societies in Indonesia, help strengthening the nation and equip people with knowledge that multi-cultural blend is something positive that can be adopted for the development of ideas and self-maturity just like what happened in the past.

\section{Literature Review}

Many kinds of research in the process of the formation of the plural Malay society have focused on several aspects. Some researchers, for example, Liaw (1993), claims that historiography consists of two elements, the myth and the history. Myth refers to sacred beings, while history deals with the historical events and real people. Both myth and history can be used to trace the origin of mankind, more specifically the Malay people as part of Indonesia people.

The Malay traditional historiography, such as Tuhfat An-Nafis, have become the object of study in several research. Matheson (1991), for instance, divided his research into three parts. The first part was about the origin of the literary work, the author, and the source of its historiography. The second part focused on the manuscript and on the process of editing the texts. The third part presented the various versions of this hikayat. Tuhfat An-Nafis has been studied by Teng (2015) in the historical framework. Noor (2014) has also studied this manuscript by focusing on the ethical values during the reigns of Johor, Riau, and Lingga. The object of his research was one of the versions of Tuhfat An-Nafis which had been kept in Trengganu.

Other manuscripts related to Riau island were studied by Kratz (1977). In his research entitled Sejarah Peringatan Negeri Johor, the treasures and the historical aspects of Johor are discussed. Yusof (1984) in another study entitled Silsilah Melayu dan Bugis explored the origin of the Malay people who might have mingled with the Bugis. The manuscript mentioned four famous Bugis people, one of which was Daeng Kamboja. The four Bugis people helped Sultan Sulaiman during the war against Raja Kecik. Similar study related to Bugis in the Malay 
region was done by Hamid (1980) based on the manuscript Hikayat Upu Daeng Menambun. He traced back the origin of Upu Daeng Menambun from the era of Sultan Muhammad until the descendants of Bugis in Sebukit.

Another study related to Riau was done by Mulyadi (1974). In his study entitled "The History of the King of Riau", he explored the origin o the Kings of Riau. In another study related to Pulau Penyengat in Riau, three researchersJulaiha et al. (2017) exposed the history and roles of Riau with numerous historical sites. Those sites have become the objects of historical tourism in Riau.

Besides Riau, there is another area, namely Siak, with historical connection with Riau. Research on Siak was done by Supandi (2015) who focused on the important role of Siak in the historical development of Riau, especially regarding the conflict between the Kingdom of Siak and the Dutch colonials. He only explored the period between 1760-1946 by taking into account the concept of pluralism in historiography.

The topic of pluralism in Indonesia has often been related with multiculturalism. The topic has been studied several times, yet any research on pluralism and its connection with the Malay are still open for discussion. Mostly the studies on pluralism in Indonesia have been based on difference in religions. One of the studies that is worth mention was done by Latifah (2016). It was said in this study that differences in religion were considered in Al-Quran as God mystery, and therefore should be accepted with no reserve. Al-Quran accepted pluralism in mankind with spiritual intrinsic or perennial value. Islam principally tolerates other religious followers to conduct their own rituals. Based on this religious tolerance, the Jews and Christianity get their total freedom. The relation between multi-religions and nationality is interesting to observe Indonesian history.

The main focus in this study is to observe the origin of the nation and ethnic groups viewed from the political aspects during the aristocracy era in the past. Smith (2003: 60) has ever mentioned that the concept of nationality was closely related to nationalism. It has become a hot topic in the discussion of modern countries with sovereignty and nationality as their ideology. There was a semi religious power that might have played in the separation of kingdoms which later created new nations. Indeed, those nations were created based on a "newly created tradition" as a result of social engineering to fulfill the interest of the elite in power. It was done through people's power during the general election. Smith considered nation as an imaginary community for political reasons to anticipate the lack of cosmic religiosity. It may happen for the nations to develop in linear time during the print capitalism emerged as the new concept.

Before the second world war, there were many scholars who believed that nations existed in each period in the history of mankind although the idea of nationalism has just emerged recently. They said that nations had existed from some time in the past. This perspective is known as perennials, something related with race and nation. Most often race has been considered as separate culture from the descendant rather than the legacy that was inherited through biological genetics known as ethnicity. 


\section{Methodology}

In the study of pluralism in historiography, especially those related to Riau, the qualitative method was taken combined with the descriptive analytic methods. The qualitative approach focuses on the social strata to find the truth. Several connections of the object being studied and the constraints were analyzed to find the answer of the questions regarding the social phenomena and to identify their roles and meanings.

The first step is the data collection from several written manuscripts in Riau as the sources. The primary as well as secondary reference was taken from literature study. The next step is to identify the aspect of the story through any related motives with pluralism in the stories. Those are stories about kingdoms as the basis of nationality in the past. Several aspects have been put into account. The political aspect can be seen through wars, succession of power, diplomacy between kingdoms, agreement between kingdoms. The economic aspect appears in trade and cruise. From the aspect of law, migration and integration of people as well as their cultural traits are considered as the identity of the Malay people.

To identify what aspect will be most prominent, it is important to analyze the motive of the story. Motive is part of the story which is repeated and connected to the pluralism among the Malay people. Motive comes up as a concept that becomes dominant through deliberate repetition. These motives have appeared through significant phrases (Abrams 1971). According to Sutrisno (1983), motives were the driving elements to the next events in the plot of the story that lead to the climax and the end of the story. The types of motives in story has been listed in Thompson (1958) and Propp (1968).

In order to understand the concept of pluralism, several opinions have been taken into account. Plural as a word means more than one, and ism is a concept or distinctive system or practice towards pluralism in Indonesia, viewed from the social, political, and religious aspects. These three aspects are controlled harmoniously so that the community may interact and live together in peace. Although there are a lot of differences, people should have great tolerance and respect to each other to live harmoniously. This awareness is important in order to accept similarities and differences among them.

Pluralism is thus considered as an attitude to admit and to understand pluralities as a positive values and blessings. This attitude has become the concept of pluralism discussed in this study. This concept is quite important to bridge the connection between members of plural communities in Malay. Pluralism can be identified from the diversities in races, religions and cultures. And without good control, it may trigger conflict that leads to separation or disintegration. When it happens, there will not be any more harmony among members of the community. The lack of harmony will threaten the disintegration of this nation as Indonesian people. Pluralism among the Malay people appeared in their literary works. This ethnic group has been living through the myths and the interaction with other ethnic groups in term of politics, economy, and social interest.

A nation, according to Grosby (2011: 9), is considered as a community in its own birthplace. When someone was born in a nation, based on his biological 
birthplace he belongs to that nation. This fact has developed in history and territorial structures within a nation. Nation is one form of relationship related to territories. Nation may exist in different territories such as different ethnic groups, countries or cities as long as there is a uniformity in culture in a long period of time.

Several factors are considered significant in the previous quotations. Those are the birthplace, biological facts concerning the birth in history, territorial structure of a cultural community in the form of kinship, and uniformity of cultures. Accordingly, the word kebangsaan (nationality) derives from bangsa (nation) in KBBI (2017) with a number of meanings. The first meaning is "about a nation" or related to nation. The other meaning is self awareness of being a member of a country. According to the meaning and concept of nation and nationality, there is a question whether the characteristics of a nation as proposed by Grosby can be used to identify the characteristics of Malay people in Indonesia as shown in the classic Malay literatures.

The next step is the analysis and the interpretation. Various data will be analyzed and interpreted by considering numerous phenomena inherent in the stories. The interpretation is performed within the context of the people during that past era, i.e., during precolonialism and colonialism. The colonial era happened during the Dutch colonialism and English colonialism. According to Ardison (2017: 26) colonialism was intended to exploit the natural resources of the colonialized country for the benefits of the occupiers, in this case for the Dutch and the English colonials. Imperialism is intended to influence every aspect of the life, especially in politics and power. From the $14^{\text {th }}$ century to the $19^{\text {th }}$ century, this event happened through a very long process. There were some important points in the history of the Malay people in their efforts to become a unified nation and ethnic group.

\section{Findings}

Based on the inventory of the traditional historiography in Riau, there are seven literary works that fit the objective of this research. These are (1) Sejarah Melayu, (2) Tuhfat An-Nafis, (3) Silsiah Melayu dan Bugis, (4) Hikayat Negeri Johor, (5) Syair Sultan Mahmud di Lingga, (6) Sejarah Raja-Raja Riau, and (7) Hikayat Upu Daeng Menambun. However, only four literary works were chosen for this paper because of their completeness in story. They are (1) Sejarah Melayu, (2) Tuhfat An-Nafis, (3) Silsilah Melayu dan Bugis, and (4) Hikayat Negeri Johor. Two manuscripts that were not chosen have smilar historical background. The historical and political backgrounds in Syair Sultan Mahmud di Lingga, and Sejarah Raja-Raja Riau could also be found in those four literary works.

The four stories that became the object of this study were the edited versions of some philologists. Sejarah Melayu was edited by Ahmad (1986), Tuhfat AnNafis was edited by Matheson (1991), Sejarah Silsilah Melayu dan Bugis was edited by Yusof (1984), and Hikayat Negeri Johor was edited by Mu'jizah (1996). 
All those literary works were related to Riau, either the topics are about Riau, or written in Riau.

Those four literary works were written in the Malay language - the language that was adopted as the national language in Indonesia on October 28 2018. The Malay language had become the pioneer of National language as well as formal state language as stipulated in the Constituent in 1945. The unitary concept is also inherent in the philosophy of Indonesia Bhineka Tunggal Ika (Unity in Diversity) that welcomes pluralism in Indonesia.

Indonesian people should keep the unity amidst the pluralities. In order to do this, it is important to trace back what and how the Malay people have kept their unity despite their pluralism. The track can be done by identifying the background, characters, and important events through the motives of the stories. The four stories have long background of time as well as numerous background of place. The stories started from the pre-colonial time to the colonial era. The places mentioned in the stories were related to the toponymy or names of places scattered in many areas. Those places were also related to the territorial places within the authorities of certain countries. Some of those places were located overseas while most of the places were in Nusantara.

The process of tracing pluralism in the stories should relate to old stories about kingdoms and the royal families. Those kingdoms had their own territories according to their political power. Some parts of the stories are also related to social and economic aspects. The economic aspect appeared in the depiction of trade activities. Another things that deserves attention is the fact that each kingdom has its own cultural elements that can be considered as the local cultures. The legal aspect appeared in mutual agreement between countries. The migration and integration in those kingdoms would eventually lead to plural nation. Several aspects in the stories will be studied through the motives of the stories.

The first manuscript to discuss is the Sejarah Melayu (the History of Malay). This is a masterpiece of Malay literature, because it described the kinship and the origin of the Malay communities. The first link began with the arrival of Raja Iskandar Zulkarain, a great King from Macedonia. The second phase described how the great King defeated many kingdoms and united them into one big power. One way of unifying power was done through marriage, for example by marrying an Indian princess, also with Chinese princess. Through marriage, his power grew immensely because of the integration of power among several kingdoms.

In the third phase, exertion of power was done through invasion. A number of countries that were defeated through war were Perak and Siam (Thailand). Sultan Iskandar Zulkarnain also defeated Tumasik (now Singapore) and became a ruler there.

Some of King Iskandar Zulkarnain descendants mentioned in the stories are King Suran, Sang Sapurba, and Wan Sundari. Just like their father, those rulers also exerted their power onto Bukit Seguntang (Palembang). In Palembang, King Suran married Mpuk Walini and Wan Empuk. Wan Sundari was King Suran daughter who later on married the ruler of Majapahit in Java. Other political-based marriage also happened with the princess from Tanjungpura, and princess from Bintan Kingdom, Sang Nila Utama. 
Son of Sultan Iskandar Syah married Putri Junjung Buih. In the Sejarah Melayu, the princess born Sang Sapurba, the king of Pagarruyung, Minangkabau. Another victory over Tumasik was also described in the story. Sang Nila Utama went to a certain place known as Tanjung Bemban in Tumasik and changed the name into Singapura because there was a lion named Tun Sri Buana.

During the process of integrating several parts of the Malay regions, the Malay princess from Singapore rejected the dowries offered by Raden Ino Mertawangsa, king of Majapahit. As a result, war between two kingdoms was unavoidable. After several wars, finally Majapahit won the war and King Iskandar fled to the Malacca Strait accompanied by his pet dog. With the help of his pet dog he overpowered a new region called Malacca. King Iskandar resided there and had three children.

Malacca then became the center of international trade. Its fame went far into Keling and a descendant of King Keling went to Malacca and married a princess of Malacca. Malacca was attacked by Siam, but survived. In the end Siam overpowered Pahang that was led by Sultan Mansur Syah. The position of Pahang became stronger, and the King of Pahang was elected as a trainer for elephants as part of its armed cavalry.

In another part of Sejarah Melayu there was a story about the migration of Arabian people to Malay. It also indicated the beginning of Islam period in Malay. Those Arabians came from Jeddah. It was told in the story that King Kecil dreamt of meeting the Rasulullah. The next morning when he woke up, he was surprised to find out that he had been circumcised and was able to read the Quran. The Arabians had good interpersonal skills and a lot of Malay people soon became the Islam followers. The king was later given the title Sultan Mahmud Syah. During his time, Adat Raja-Raja Melayu was created.

The vast expansion of Malay kingdom also reached Pasai. Merah Silu was told to grant gold with the grandson of Raja Ahmad. He then build the kingdom of Pasai. Pasai was considered as a powerful kingdom in Malay. Several scriptures and inscriptions found in Pasai cemetery showed that it had its golden era in the past.

The power of Malay kingdom expanded widely until it reached Makassar (Raja Semerluki) and Patani. However, the power began faltering with the arrival of Peringgi ship from Goa. Alfonso de Albuquerque, king of Peringgi attacked Malacca. Because of Sri Nara Diraja, Malacca survived and the Peringgi went back to Goa. King Peringgi with its strong navy attacked Malacca again, and finally succeeded in defeating the Malacca arm forces. Sultan Mahmud Syah fled to Pagoh, from Pagoh he went to Muar, and finally reached Bintan. Paringgi pursued him by attacking Bintan. Sultan Mahmud Syah fled again to Kampar, an inland areas surrounded by woods.

In Silsilah Melayu dan Bugis some examples of pluralism were shown through the descendants of King Malay and King Bugis with the migration of Putri Balkis, Siti Malengkai who married King of Macedonia. From the marriage, born La Madusilat. He was the first Islam ruler in the region. This king had 5 children: Daeng Perani, Daeng Menambun, Daeng Celak, Daeng Kemasa, and Daeng Marewa. Those five Daeng went to Malay and married Malay princesses. 
The integration of Bugis and Malay people took place widely in Riau, and the expansion went to Siantan.

The power of Bugis people and Malay in Riau became stronger because of the leadership of Sultan Sulaiman, king of Riau. He successfully made Riau as a popular center for trade, even the Chinese people came there to trade gambier. Many Sayeed also came from Arab for trading. They lived in the mosques. Johor also enjoy prosperity in trading. The ethnic groups from Johor was popular among the Malay people because of their brave adventures. To expand its power the Bugis people also married princesses from Malay.

Bugis people dominated the maritime trade. They also succeeded in expanding their power in politics. During the reign of Sultan Sulaiman, Riau became part of Bugis domination. Their sole enemy was Raja Kecik from Minangkabau who ruled Siak.

Five Bugis descendants expanded Bugis power onto several areas in Malaysia, i.e., in Kedah, Selangor and Siantan. Some of them also went to Sambas and Mempawah in Borneo. Formerly Daeng Kemase and Daeng Menambun went to Sambas to pay a visit. In Sambas, Daeng Kemase married Tun Tengah, the Sultan's sister from Sambas. Daeng Menambun went to Mempawah and married the princess also daughter of Sultan Mempawah.

Another descendant of Bugis, Jamril, went to Dayak and did some trading there. Later on he refused for a proposal to marry a Dayak girl. Afterwards, came Daeng Rilaka to continue the business with the Dayak people. Through this trading, Bugis successfully overpowered Dayak. Another Bugis man went to Batavia to help the Dutch colonial fighting against the Chinese people. He joined the high officials in Batavia.

In another story, Tuhfat An-Nafis, the Bugis people succeeded to expand their power to Tumasik (now Singapore). Some parts of this story are similar to the parts narrated in other stories. With skillful strategies, the Bugis people allied with Sultan Sulaeman and became Raja Muda in Riau. Political marriage was frequently performed by the Bugis people to strengthen their power in Malay lands.

The interesting part of the story was when Raja Haji, a descendant of a Bugis king fought against Dutch infiltration to the Malay islands. The Dutch colonial at that moment had occupied most of the Malacca Straits. The Dutch armed forces tried to attack Malay but failed because of Raja Haji's opposition. Finally, the Dutch officials agreed to sign an agreement.

Raja Haji was eventually defeated by the Dutch colonial because of the tricky agreement. The Bugis people in Riau and Lingga fled to Rembau. In this story, Sultan Sulaiman was told to ally with the Dutch. After he deceased, his throne was succeeded by Sultan Ahmad who was still 8 years old. During this era, Raja Haji showed his patriotic opposition. He held the position of Engku Kelana.

Raja Haji allied with Sultan Indragiri to attack Minangkabau. During that time, drug deal was still legal, and Yang Dipertuan Muda was able to pay his debt to the Dutch from drug trading. When Raja Haji took a voyage to Malacca, his ship was stolen and drowned. Raja Haji went to Malacca and asked for reimbursement for his loss. The Dutch agreed to pay the compensation. Soon 
afterwards Raja Haji was appointed as Yang Dipertuan Muda in Riau. Bugis people became prosperous which caused jealousy among the Malay people.

One day a conflict erupted between Raja Haji and the Dutch colonial about profit sharing, and this initiated a war between them. The war took place in Pulau Penyengat for about a year long. Riau was aided by people in Selangor and eventually the Dutch retreated from Malacca. Later on, the Dutch people were cornered in Teluk Ketapang, because the help of arm forces from Batavia, the warring parties were equally strong. Raja Haji was killed during the war, but the Dutch failed to occupy Teluk Ketapang when King Tempasok came for help. After the Dutch troops retreated from Teluk Ketapang, Sultan Mahmud chose to stay in Pahang, and then moved to Trengganu. He begged Sultan Trengganu for reconciliation, but the Dutch rejected the request.

In 1795 the UK took over Malacca. Sultan Mahmud was then legitimized as the ruler in Riau. He built the palace in Siak. When he passed away, Raja Abdul Rahman was appointed as his successor. At the same time, the Dutch colonial was building a customs office in Tanjung Pinang. The Dutch occupied the areas and protected themselves by setting up cannons. A Bugis man, namely Arong Birawa, was paid monthly to guard the place.

In the Hikayat Negeri Johor (Mu'jizah 2018) the concept of pluralism appeared in the power shared by the Johor and Jambi. Conflict between them happened in Johor in 1672 during the leadership of Sultan Abdul Jalil Syah I. The Sultan moved to Pahang because Johor was attacked by Jambi. Afterwards Tun Abdul Jamil built a palace and kingdom in Riau next to river Carang. When the Sultan Abdsul Jalil Syah I passed away, his throne was succeeded by Sultan Ibrahim from Pahang who sometimes lived in Riau

Sultan Abdul Jalil Syah II was appointed in Makam Tauhid in 1700 AD. Unfortunately, his palace was on fire. He moved to Riau. During his leadership, Riau was being attacked by the Minangkabau in 1717 AD. When he passed away, Sultan Sulaiman was appointed as his successor. Sultan Sulaiman was backed up by 5 Bugis warriors: Kelana Jaya Putra, Daeng Perani, Daeng Menampuk and two others. Raja kecik came to attack the kingdom, but defeated by the Bugis in 1721 AD. After the appointment of Sultan Sulaiman, the Bugis people were granted high position in the Kingdom. Daeng Menambun became raja tua (the elder king) while Kelana Jaya Putra became raja muda (the younger king). Later on the Bugis people married Malay women. Daeng Perani married Tun Iring, Daeng Menempuk married Tun Tifah, Daeng Mesuru married Tun Kecik, Putra Marhum Muda, Daeng Mangsuk married Tun Aisyah.

There was a conflict between the Bugis people and Sultan Sulaiman that made him move to Bulang in 1723 AD. Raja Kecik from Minangkabau together with Raja Emas and Daeng Matekah attacked Riau saveral times but failed. In 1736 Daeng Kamboja was elected as Raja Muda in Selangor. He was accompanied by Raja Haji, son of Marhum Mangkat.

Raja Haji from Selangor married Encik Aisyah. When his wife passed away, he married again to Encik Sejuk, King Amaran's daughter. The conflict between Raja Sulaiman and Raja Muda because Sultan Sulaiman was pro the Dutch colonial and he made friend with Raja Buang. Raja Buang was Raja Kecik's son 
who fought against his brother, Raja Alam. Raja Buang lost the battle, and went to Sultan Sulaiman to ask for help.

Raja Haji and Raja Muda in Lingga were attacked by twelve warship from Malacca. Raja Haji fought back and wounded. He went to Riau afterwards. Yang Dipertuan Muda together with Raja Rembau and Raja Alam decided to attack Malacca. On the journey to Malacca, the defeated many countries such as Peringgah, Tengkera, Keling, Bukit Cina and Teluk ketapang. Each conquered country then became their basecamp for defense. Malacca got help from Batavia during the war. After eight months both parties agreed to set cease fire. They went home and soon afterwards, Raja Haji married daughater of Raja Perak.

When Sultan Sulaiman in Riau, the Dutch colonial called him for political negotiation. He came to Bunga Rama accompanied by Tengku Selangor, Penggawa Miskin and Nakhoda Tauli. They continued their trip to Pedas and then to Asahan, went on to Malacca and ended in Lingga. When they arrived at Lingga, there was an emissary from Jambi who asked Raja Haji to go to Jambi. In Jambi, Raja Haji was granted a new title, Pangeran Sutawijaya. He married Kadar, daughter of King Indragiri. As recorded in historiography, there were wars against Raja Hijau and Raja Bayang. Afterwards, Raja Haji or Pengeran Sutawijaya proceeded his journey to Kuala Cinaku and built a kingdom there.

One day, the Dutch fleet came to Lingga and seized King Yusuf properties. They brought the spoils of war to Malacca. Raja Muda Daeng Kamboja pledged Raja Haji to take back the property, and finally the Dutch returned it to him. It was brought to Riau, afterwards, Raja Haji went to Selangor and married Raja Salamah. He also went to Pangkor and married Raja Indud. From the marriage, they got a son, named Raja Jafat. Afterwards, Raja Haji returned to Riau when he got the news that Raja Muda Daeng Kamboja passed away. In the end Raja Haji was appointed as the new ruler in Riau by Sultan Mahmud II and Datuk Bendahara.

One day there was a fleet from Benggala and the Dutch attacked them in Tanjungpinang and brought the ship to Malacca. Previously there had been an agreement between Raja Haji and the Dutch colonial, that whoever got booty, it sould be shared between both. The Dutch broke their promise. He decided to attack Malacca and built his defense camps in Selangor, Rembau, Pedas and Batang Tiga. The Dutch people got help from nine warship from Batavia. During the war in Ketapang Bay, Raja Haji and Daeng Selikan were killed.

The four historiographies mentioned above contained a record of what happened in the past during the existence of the Imperium in Riau. Migration and relationship among several ethnic groups eventually formed the Malay people that we recognize nowadays. Thus, it is safe to say that the Malay people derived from several kingdoms in various location. The integration of those ethnic groups was repeated in the stories. The motives that led to the integration were marriage, war, and trade. 


\section{Marriage Motive as a legitimacy and Unitary Exertion for Power}

During precolonial time, integration among various ethnic groups was the result of marriages. Marriage is not intended only to build a new family, but it also functions as exertion of power. There were normal marriages as well as political marriages in the historiography.

Model of marriage in Sejarah Melayu shows the kinship and the origin of the Malay rulers. Commonly it would be narrated in the initial part of the story. The first marriage mentioned was between Sultan Iskandar Zulkarnain from Macedonia and a Hindi princess. The second marriage was between King Culan and Putri Mahabbatul Bachri, a sea goddess, daughter of King Aftagul. The manuscript also mentioned another marriage between Sultan Iskandar Syah and Putri Junjung Buih. From the marriage, they got three sons-Sang Sapurba who later became King of Pagarruyung, Minangkabau, Putra Tanjung Pura, and Sang Mantaka. The last later on lived in Palembang and got a son, namely Demang Lebar Daun.

Mariage is like a myth to legitimize power in Malay. Because their forefather was Sultan Isakndar Zulkarain, the powerful ruler of Macedonia, the Malay descendants became outstanding people too. The women to whom Sultan Iskandar Zulkarnain married, were also distinguished people. An Indian princess and the other is a sea goddess which symbolize the power of nature. It implies that the Malay people were strong people because of their outstanding ancestors.

There was also another marriage between the descendant of Malay people from Tanjung Pura and Raden Galuh Kesuma, the daughter of King Majapahit, Raden. Thanks to Hang Tuah that made the marriage possible. The Sultan in Malacca married daughter of King Majapahit and brought her to Malacca. Therefore, there was a kinship between the Malay people and those from Majapahit, from East Java.

Political alliance through marriage was done by King Cina who married his daughter Hang Liu to King of Malacca. To make it possible, the King from China send ship full of needles. At that moment, needle was considered a precious thing. To repay the gift, King Malacca sent a ship full of sago and rending. Because of the marriage, Malacca and China became ally.

In Silsilah Melayu dan Bugis interracial marriage happened during the marriage of a Balkis princess, Siti Malengkai and King of Macedonia. From the marriage, they got a son, La Madusilat. Later on he became the first ruler who embraced Islam as his religion. La Madusilat got 5 bugis sons, they were Daeng Perani, Daeng Menambun, Daeng Celak, Daeng Kemasa, and Daeng Marewa. To extend their power, those five sons went to Malay island and married Malay girls. Because of the marriages, there was strong kinship between the Bugis and the Malay people in Riau.

La Madusalat had three sons. The eldest was Upu Daeng Rilaka who later became King of Luwuk. The second was Upu Daeng biasa who took adventure to Java island and resided in Batavia. The third son, Upu Daeng Rilaka married a female ruler from Topamma and got a son, named Datu Ruatu. Daeng Rilaka went to Makassar accompanied by Arung, king of Bone. Later on, Daeng Rilaka went 
to Batavia. He borrowed some money from his brother Upu Daeng Biasa to buy a ship. It is a special warship, and he continued his journey to several parts of Malay islands and occupied several countries.

In Hikayat Negeri Johor, political marriage also described between Raja Haji and women from other regions. The first woman he married was from Selangor. The second was the daughter of King Jambi, and the third wife was the daughter of the Great King of Indragiri. Relationship among various kingdoms improved significantly because of the political marriages.

Riau also initiated a close relationship with the Bugis people through marriage. Four Bugis people who had helped Sultan Sulaiman married Malay girls from Riau. Daeng perani married Tun Irang, Daeng Menemmpuk married Tun Tifah, Daeng Mesuru married Tun Kecik, and Daeng Mangsuk married Tuna Aisyah. These happened in 1723 AD. Through marriage, there will be blood kinship among those kingdoms. Children born from interracial marriage became Bugis-Malay descendants. Raja Ali Haji was one of them. This kinds of marriage was narrated in Tuhfat An-Nafis, too.

\section{War as an Expansion of Power}

According to KBBI (2017), war results from a conflict between two countries, two nations, two religion or two ethnic groups. War in historiography has become one of the motives of the story. It happened because of the decision to exert power and to occupy wider regions. In Sejarah Melayu the war happened between Maharaja Dewa Dura who attacked Pahang, but he failed to occupy this region. Pahang at that moment got help from Sultan Mahmud from Riau. Because of this, Pahang and Riau became alliance.

A famous war in Sejarah Melayu happened when Peringgi attacked Malacca. The later was central of international trade at that time. The fleet from Peringgi coming from Goa and attacked Malacca. However, the attack which was led by Alfonso de Albuquerque failed to occupy Malacca because of Sri Nara Diraja, a brave knight from Malacca who fight against them. Peringgi retreated to Goa, yet the next invasion from Peringgi managed to defeat Malacca in 1511 AD.

Several attacks on Malacca by the European people were described in Sejarah Melayu. Other than Peringgi, Malacca has been occupied by the Dutch colonial. The Dutch defeated Peringgi and took over Malacca. In the end, Britain beated the Dutch and took over Malacca.

War as the motive of the story could also be found in Hikayat Negeri Johor. It happened among tribes. One of the war mentioned was between the alliance of Malay Kingdoms and the Minangkabau kingdom. Malay fleed were led by Nakhoda Sekam, while Minangkabau was led by King Kecik. The war made Riau went to find other allies. The alliance between two countries and more was intended as the means of diplomacy to maintain the power. Riau then asked Bugis for help. Therefore, Sultan Sulaiman sent his four emissaries to the east to get help from Bugis. They were Kelana Jaya Putra, Daeng Kamboja, and two others.

The Malay kingdom with the help of the Bugis people managed to defend Riau from Minangkabau attack. Afterwards, there was close relationship between 
the Bugis people and the Malay people. Daeng Kamboja from Bugis was appointed as Raja Muda later on.

Daeng Ali also united several small kingdoms into by attacking Selangor. Raja Sulaiman also sent his emissaries to several kingdoms, such as Ungaran, Pahang, and Trengganu for diplomacy. From these diplomacy, they build their alliance to make them stronger.

In Hikayat Negeri Johor war events happened several time. One of them happened when Raja Haji in Lingga was invaded by 12 warships from Malacca. Raja Haji fight against the attack and got wounded. He retreated to Riau. He built the power and decided to make a counter attact with the help of Raja Rembau and Raja Alam. On their journey to Malacca, they also beat several countries such as Peringgi, Tengkera, keeling, Bukit Cina, and Ketapang Bay. Each of them later on became the basis of his defense to attack Malacca. Formerly, Malacca was almost defeated, but with the help of 9 warships from Batavia, they managed to protect Mallaca. After nine months of war, both parties agreed to set a cease-fire.

However, the Dutch broke their promise, and Raja Haji went to Malacca to claim his rights. When Raja Haji returned to Riau, Malacca attacked him. During the war, Raja Haji lost the battle and died in Ketapang Bay. After his deceased, Riau continued their defense against the Dutch invasion. Eventually, the Dutch colonial managed to occupy the region, and they built their fortress for defense.

\section{Trade as an Expansion of Economic Power}

Trade is related to activities of buying and selling with profit orientation. In historiography, trade was not merely for the sake of getting profit but also for power expansion. In Hikayat Negeri Johor, for example, during the leadership of Sultan Sulaiman, Riau became a prominent center for business and trade. Even the Chinese traders came there for business. They sold Gambier. Also many Sayeeds from Arabian countries came for trading and they stayed in the mosques. Advanced trading also happened in Johor. This lucrative condition drew the European people, especially the Dutch people and the British people to come, not only for trading, but also to occupy the region.

In Silsilah Melayu dan Bugis one of the Bugis people's enterprise is trading. Because of their skills in maritime, they dominated the maritime trade. While doing some business, they also expanded their territories. Riau became one of Bugis territories. Raja Kecil from Minangkabau who overpowered Siak became Bugis main competitor.

Bugis also expanded their power to other regions such as Kedah, Selangor, Siantar, and several regions in Borneo such as Sambas and Mempawah. Formerly, the Bugis came to Sambas because of an invitation. There came Daeng Kemase and Daeng Menambun to Sambas. Daeng Kemase married the Sultan's sister, Tun Tengah. Daeng Menambun went to Mempawah and married the princess of King Mempawah.

Jamril, the descendant of Bugis people, went to Dayak for trading and was proposed to marry a Dayak girl, but he refused. Daeng Rilaka then went to Dayak and began the trade with the Dayak tribes. Finally, the Dayak was overpowered by 
the Bugis people. Another Bugis descendant, Upu Daeng Biyasa even succeeded in joining the Dutch colonials by helping them to fight against Chinese people in Batavia.

\section{Discussion}

Riau in the $18^{\text {th }}$ and $19^{\text {th }}$ centuries has become the center of the Malay imperium. The capital city of this kingdom moved from Johor, to Riau, and then to Pahang, and to Lingga. Riau has a very strategic location as the center of Malay civilization. Based on Traktaa London in 1824, Riau became the dominion of the Dutch colony. This island functioned as a transit for trade where several nations met as traders. Other than trading, some people also came to Riau for religious teaching. They brought with them their native cultures that impacted the local people. This is evident in Riau communities.

The word Riau derived from rio means "sungai" or river in English. It is a word taken from the Portuguese. Sooner or later the word change its spelling into Riau while the Dutch people used to write Riow. Another theory said that Riau derived from rioh which means similar sound, or can also mean noisy. This notion might have been inspired by the fact that Riau had been a crowded center for trade in the past time. Sultan Ibrahin Syah the Malay ruler from 1671-1682 named the place as Bandar Rioh (Mu'jizah and Rukmi 1998: 8). The Malay imperium in the past has significant role in the history of the Indonesia. Malay was the origin of Indonesian root. The main clue for this national identity is the use of Malay language as the national language in Indonesia. It functioned as the language for communication among the kingdoms. The Malay language also became the lingua franca. In the process of Indonesia's independence, this language was adopted as the national language on October 28, 1928-a unitary language functioning as one of the identities of the Indonesian people as stipulated in the Constituent UUD 1945 and legally confirmed in the Regulations of the Republic of Indonesia no. 24, 2009 regarding the use of flag symbol, language, and national logo and anthem.

The Malay language also had its strategic role as the language for diplomacy among kingdoms and with the Dutch and English colonials. A number of research studies were done by Gallop (1994) on the letters written in the Malay language as diplomacy communications between kings in Nusantara and the English colonial authorities. The letters for communication between the kings and the Dutch colonial authorities were studied by Mu'jizah (2009). Those letters were written in the Malay language using Javanese scriptures and sent by the kings of Banten, Madura, Riau, Banjarmasin, Pontianak, Aceh, and Ternate.

The Malay language has been used in several kingdoms in Nusantara for political reasons. Kingdoms in the past had independent power to decide their own language for communication. Among various ethnic groups in Indonesia, the Malay language was chosen as the unitary language among numerous kingdoms with a number of variation and dialect based on local usage. These variations and different dialects in the Malay language indicate that there is pluralism in the language. 
From the above description, it is evident that many nations and ethnic groups came to Malay island from all over the world, including the Balkan countries and Arab world, as well as the Malay people who lived in Thailand, in Malaya, and in Tumasik (now known as Singapore). The ethnic groups involved the Bugis people, the Makassar, the Minangkabau, and the Dayak people.

During that era, many ethnic groups and nations mingled and interacted to each other. But some characteristics can still be recognized nowadays. Some of the characteristics are related to their biological traits, such as, for example, of those from India, some European countries, such as Portugal, the Netherlands, the Great Britain, and some Asian countries, such as China, Thailand, Malaysia, and Singapore. They can be easily distinguished by looking at their physical appearance. A lot of ethnic groups in Indonesia have also distinctive features physically, but those features are only subtle. The most significant factors that distinguish Indonesian ethnic groups from each other are their local nature and native cultures. The Bugis and Makassar ethnic groups who live in the coastal areas have different physical characteristics than the Dayaks who live in the inland areas surrounded by woods.

Various ethnic groups in Indonesia in the past had full political power across their own territories. It is evident from the documents that show the diplomacy between the kingdoms and with the Colonials. Every kingdom had its own authority in governing their own regions (see Gallop 1994, Mu'jizah 2009).

The dispersion of people can be shown in the map of nations and ethnic groups migration to the Malay regions which center was in Riau, especially the Riau island as it is known nowadays. The map shows the migration of numerous nations and ethnic groups who integrated to create a close relationship known as the Malay ethnic group. The pluralism in Malay can be found in several aspects, one of them is in the stories' motives.

Three motives, namely, marriage, war, and trade, triggered the integration and migration of various nations and ethnic groups which later on have constructed the Malay ethnic group with its pluralities. Marriage belongs to both social and political aspects. War, diplomacy and agreement belong to the political aspect, while trade belongs to the economic aspect.

Those three aspects showed the migration and diasporas, and how various kinds of society have mingled and integrated. In the history of Malay, several places were mentioned, such as Macedonia, Hindi, China, Siam (Thailand), Keling, Portuguese, Arab and Jedah, Malacca, Tumasik (now Singapore), Perak, Semerluki, Bukit Siguntang, Majapahit, Bintan, Pahang, and Pasai. Some of those names have changed into popular names we know nowadays, such as Palembang for Bukit Siguntang, India for Keling, Aceh for Pasai and Macassar for Semerluki. A number of names of locations was also mentioned in the history of Malay (Sejarah Melayu), but they are not included in this essay.

The names of locations implied how vast the diaspora dispersion was. The dispersions were based on several reasons, such as power expansion, trade, and religious teachings. Several names were identified as centers of power. Macedonia was the greatest Islamic state at that moment. This area belonged to the Greek authority with its borders to Kosovo, Serbia, Bulgaria, and Albania. Macedonia 
reached its golden era during the authority of Alexander the Great (Soeratno 1991). Indi or India/Keling, and China had strong influence in the international trade. The Portuguese also did the expansion for trade. Arabs and Jeddah migrated for religious reasons. Religion of Islam got its popularity along with the development in international trade to Aceh, Ternate, and other coastal areas in Java. Aceh, whose name was Samudra Pasai at that era, was Malacca Ally. Malacca was taken over by the Portuguese after they defeated Samudra Pasai.

Malacca, Perak, and Pahang now belong to the territory of Malaysia. Tumasik has become Singapore, and Siam has become Thailand. In the history of Malay, Siam or Thailand invaded the Malay kingdoms several times. Terengganu and Kelantan were once Siam's dominions. Other regions in Southeast Asia mentioned in the history of Malay were Majapahit (in East Java), Palembang, and Pasai (Aceh).

Malacca with its strong trade dominated several parts of the Malacca Straits during that era. Clove became the best commodity from Malacca. Spices, such as pepper, were also in trade. The route was globally known as the silk-road ranging from China and India to Southeast Asia. Among other commodities were gold, camphor, and sandalwoods.

The migration and diaspora in Malay started around the $14^{\text {th }}$ century. According to Kleden (2017), this era was known as the period of international migration. Diaspora among many people in the world happened because of power expansion and trade. During the migration, assimilation among different cultures took place to create a new identity known as the origin of new ethnic groups. Eventually those ethnic groups represented by the kingdoms united to create the new ethnic group known nowadays as the Malay people.

\section{Conclusion}

Based on the traces in traditional historiography, it is evident that historiography may function as a social document that mirrors the lifestyle of people in the past. In other words, it is an authentic record of how ancient people lived to form a nation. The Malay people in the past lived in independent territories within separate kingdoms. In those locations, the Malay communities lived and grew to create their own family trees. The studies of family tree have shown that the Malay communities were constructed of plural communities.

The plural communities in Malay were bound by a unitary language known as the Malay language. This language had important roles in the development of the Indonesian people. The language which was once the lingua franca was then adopted as the national language among various kinds of local languages in Indonesia. This language became bahasa Indonesia when the Malay people became part of Indonesia.

In four historiographies in Riau, it was evident that the formation of the Malay people was influenced by the interaction of multicultural and multi-ethnic groups in Riau island. Riau was a significant place for trade and advancement compared to other regions because of its close proximity to Malacca as the center 
of trade, and became the capital city of the Malay imperium instead of Johor and Lingga. Riau was also considered as the center of maritime because of its land features. Riau consists of several islands with abundant natural resources from land and from the sea. It is understandable that Riau at that moment attracted many visitors from various regions and nations.

As an advanced territory, Riau became a popular place for intercultural communication in the world. During these encounters, some competition might have occurred in trade, politics. There were also social changes. Those three aspects have influence the plural characteristics among the Malay people. Those three aspects appeared in three motives in the historiography - the marriage, the war, and trade.

Marriage is a social aspect which influences the political aspect. According to the myth, the kinship of the Malay people began with the marriage of Sultan Iskandar Zulkarnain from Macedonia and an Indian princess. The King also married a sea goddess, and a divine princess named Putri Junjung Buih. Malay people in Palembang, Pagarruyung, and Tanjung Pura were believed to be the descendants of that royal couple. Macedonia and India at that moment were great and powerful countries; therefore, the marriage would legitimize the power of the Malay people among other ethnic groups. The divine marriage also symbolizes the harmonious unity between the microcosm and the macrocosm.

Marriage is the most powerful knot in kinship based on the social aspect. Through marriage the biological traits are inherited to create a new offspring. Marriage is also a good means for unifying power in politics. The marriage of the Sultans to princesses from other powerful countries or kingdom can also be considered as a political bound. Through marriage, those two nations will become stronger and closer to each other which later on will construct the emergence of the Malay people.

Malay people have been widely known as famous traders because of their richness in natural resources. Due to their location within maritime region, many people from other countries came to Riau to negotiate during the reign of Sultan Sulaiman. Those people were the Portuguese (known in the manuscript as Peringgi), English, Dutch, Indians, Arabs, and Chinese. There was no detailed description about international trade in the region. The manuscript only mentioned that during the reign of Sultan Sulaiman, trade and business in Riau, Johor, and Lingga were enormous. It became more lucrative with the arrival of the Bugis people.

In addition to marriage as social aspect, there was war that played an important role in the multi-cultural migration. The wars mentioned in the manuscript happened between the Malay people and the Dutch colonies, and between the Malay people and the Bugis and the Minangkabau. During these tribal wars, the stronger would occupy wider areas and procured more power in the regions. Therefore, the expansion for unitary mission of power grew wider.

Along with those motives and social aspects, the Malay people became a plural nation in their development. Both origins and kinships are important as reminders for the Malay people who have become part of Indonesia to protect the unity among people and to prevent the country from disintegration. These efforts 
are worth noted as important lessons from the past of the formation of the Indonesian people.

\section{References}

Abrams H (1971) The Mirror and the Lamp Romantic Theory and the Critical Tradition. Oxford: Oxpord Unversity Press.

Ahmad AS (1986) Sejarah Melayu (Malay History). Kuala Lumpur: Dewan Bahasa dan Pustaka.

Ardison MS (2017) Diponegoro dan Perang Jawa (Diponegoro and the Java War). Surabaya: Ecossystem.

Badan P, Bahasa P (2016) Peta dan Bahasa-Bahasa Daerah di Indonesia (Maps and Regional Languages in Indonesia). Jakarta.

Gallop A (1994) The Legacy of Malay Letters, Warisan Warkah Melayu. London: British Library.

Grosby S (2011) Sejarah Nasionalisme: Asal Usul Bangsa dan Tanah Air (History of Nationalism: The Origin of the Nation and the Motherland). Yogyakarta: Pustaka Pelajar.

Hamid RA (1980) Hikayat Upu Daeng Menambun. Kuala Lumpur Dewan Bahasa dan Pustaka.

Julaiha, Ridwan M, Tugimin (2017) Peranan Pulau Penyengat sebagai objek sejarah di kota Tanjungpinang, Provinsi Kepulauan Riau (The role of Penyengat Island as a historical object in the city of Tanjungpinang, Riau Islands Province). Pekanbaru: Universitas Riau. Retrieved from http//repositori.unri.ac.id.

KBBI-Kamus Besar Bahasa Indonesia (2017) Jakarta: Badan and Bahasa.

Kleden I (2017) "Sastra dan Kebhinekaan" ("Literature and Diversity"). Seminar Kritik Sastra. Jakarta: Badan and Bahasa.

Kridalaksana H (1998) Masa Lampau bahasa Indonesia (Past Indonesian language). Jakarta: Kanisius.

Kratz U (1977) Peringatan Sejarah Negeri Johor (History of Johor State History). Wiesbaden: Otto Harrassowitz.

Latifah T (2016) Perenialisme. Tsarwah 1(1): 85-93

Liaw YF (1993) Sejarah Kesusastraan Melayu Klassik (History of Klassik Malay Literature). Jakarta: Erlangga.

Matheson V (1991) Tuhfat An-Nafis. Kuala Lumpur: Fajar Bakti.

Melalatoa JW (1995) Ensiklopedia Suku-Suku Bangsa di Indonesia L-Z (Encyclopedia of Ethnic Groups in Indonesia L-Z). Jakarta: Departemen Pendidikan dan Kebudayaan.

Mu'jizah (1996) Hikayat Negeri Johor. Jakarta: Pusat Bahasa.

Mu'jizah (2009) Iluminasi dalam Surat-Surat Melayu Abad ke-18 dan ke-19 (Illumination in Malay Letters of the 18th and 19th centuries). Jakarta: KPG-EFEO.

Mu'jizah (2013) Skriptorium Naskah Riau: Koleksi Perpustakan Leiden (Riau Script Scriptorium: Leiden Library Collection). Yogyakarta: Diandra.

Mu'jizah (2018) Historiografi Tradisional, Raja-Raja Melayu, dan Kekuasaan dalam Hikayat Negeri Johor (Traditional Historiography, Malay Rulers, and Power in the State Hikayat of Johor). Journal of Atavism 21(11): 17-34.

Mu'jizah, Rukmi MI (1998) Penelusuran Naskah Riau: Kajian Kodikologi (Riau Script Search: Kodikologi Study). Depok: Program Penggalakan Naskah Nusantara. 
Mulyadi Sri WR (1974) "The History of the King of Riau". Paper in Sixth International Conference on Asian History, International Assosiations of Historians of Asia (IAHA), Yogyakarta, August, 26-30.

Noor AM (2014) "Menelusuri Nilai Etika dlam Pemerintahan Johor-Riau-Lingga menerusi Naskah Tuhfat An-Nafis versi Trengganu" ("Tracing the Ethics Value of the Riau-Lingga Government through the Trengganu version of the An-Nafis Text"). Naskah dan Relevamsinya dalam kehidupan Masa Kini. Padang: Universitas Andalas.

Propp V (1968) Morphology of the Tale. Leningrad.

Smith S (2003) Nations and Nationalism in a Global Era. Cambridge: Polity.

Soeratno SC (1991) Hikayat Iskandar Zulkarnain: Analisis Resepsi (Hikayat Iskandar Zulkarnain: Reception Analysis). Jakarta: Balai Pustaka

Supandi A (2015) Kesultanan Siak Sri Indrapura: Islam dan Perlawanan terhadap Kolonialisme pada tahun 1760-1946 (The Sultanate of Siak Sri Indrapura: Islam and Resistance to Colonialism in 1760-1946). Jakarta: UIN Syarif Hidyatullah.

Sutrisno S (1983) "Sastra dan Historiografi Tradisional" ("Traditional Literature and Historiography"). Panel Historiografi Tradisional. Jakarta: Proyek Inventarisasi and Dokumentasi Sejarah.

Teng HMBA (2015) Tuhfat An-Nafis: Karya Sastra Sejarah (Melayu) dalam Persfekif Sejarah (Tuhfat An-Nafis: History Literary Works (Malay) in the Historical Perspective). Makassar: Universitas Hasanuddin.

Thompson S (1958) Motif-Index of Folk-Literature. Bloomington: Indiana University Press.

Yusof M (1984) Silsilah Melayu dan Bugis dan Sekalian Raja-Rajanya (The Malay and Bugis pedigree and all the Kings). Kuala Lumpur: Fajar Bakti. 
